Article

\title{
Simultaneous Adsorption of Heavy Metals from Roadway Stormwater Runoff Using Different Filter Media in Column Studies
}

\author{
Tadele Measho Haile * and Maria Fuerhacker \\ Institute of Sanitary Engineering and Water Pollution Control, Department of Water-Atmosphere-Environment, \\ University of Natural Resources and Life Sciences, Muthgasse 18, 1190 Vienna, Austria; \\ maria.fuerhacker@boku.ac.at \\ * Correspondence: tadele.m.haile@boku.ac.at
}

Received: 29 May 2018; Accepted: 23 August 2018; Published: 29 August 2018

\begin{abstract}
Stormwater runoff from roadways often contains a variety of contaminants such as heavy metals, which can adversely impact receiving waters. The filter media in stormwater filtration/infiltration systems play a significant role in the simultaneous removal of multiple pollutants. In this study, the capacity of five filter media - natural quartz sand (QS), sandy soil (SS) and three mineral-based technical filter media (TF-I, TF-II and TF-III) - to adsorb heavy metals ( $\mathrm{Cu}$, $\mathrm{Pb}$ and $\mathrm{Zn}$ ) frequently detected in stormwater, as well as remobilization due to de-icing salt $(\mathrm{NaCl})$, were evaluated in column experiments. The column breakthrough data were used to predict lifespan of the filter media. Column experiment operated under high hydraulic load showed that all technical filters and sandy soil achieved $>97 \%, 94 \%$ and $>80 \%$ of $\mathrm{Pb}, \mathrm{Cu}$ and $\mathrm{Zn}$ load removals, respectively, while natural quartz sand (QS) showed very poor performance. Furthermore, treatment of synthetic stormwater by the soil and technical filter media met the requirements of the Austrian regulation regarding maximum effluent concentrations and minimum removal efficiencies for groundwater protection. The results showed that application of $\mathrm{NaCl}$ had only a minor impact on the remobilization of heavy metals from the soil and technical filter media, while the largest release of metals was observed from the QS column. Breakthrough analysis indicated that load removal efficiencies at column exhaustion (SS, TF-I, TF-II and TF-III) were $>95 \%$ for $\mathrm{Cu}$ and $\mathrm{Pb}$ and $80-97 \%$ for $\mathrm{Zn}$. Based on the adsorption capacities, filtration systems could be sized to 0.4 to $1 \%$ (TF-I, TF-II and TF-III) and $3.5 \%$ (SS) of their impervious catchment area and predicated lifespan of each filter media was at least 35, 36, 41 and 29 years for SS, TF-I, TF-II and TF-III, respectively. The findings of this study demonstrate that soil—based and technical filter media are effective in removing heavy metals and can be utilized in full-stormwater filtration systems.
\end{abstract}

Keywords: stormwater treatment; filter media; heavy metals; adsorption; de-icing salt; lifespan

\section{Introduction}

Stormwater runoff from vehicle trafficked areas and roofs contains a heterogeneous mixture of pollutants including solids, heavy metals, organic pollutants, such as polycyclic aromatic hydrocarbons (PAHs), and mineral oil hydrocarbons ( $\mathrm{MOH})$, nutrients and compounds of de-icing salts, which can cause significant hydrological and ecological impacts on receiving waters [1-3]. Heavy metals such as cadmium $(\mathrm{Cd})$, chromium $(\mathrm{Cr})$, copper $(\mathrm{Cu})$, lead $(\mathrm{Pb})$, nickel $(\mathrm{Ni})$ and zinc $(\mathrm{Zn})$ are the most frequently reported pollutants in roadway and parking lot runoffs, mainly emitted from vehicles and traffic-related activities [3-6]. Heavy metals are mobile in natural water ecosystems, non-degradable and potentially toxic, as they can accumulate in the environment causing both short term and long 
term adverse effects $[7,8]$. Furthermore, various studies noted that roadway runoff are likely to induce mutagenic/genotoxic effects due to the combined effects of heavy metals and PAHs $[9,10]$. Consequently, treatment of stormwater has become increasingly important to mitigate its negative ecological effects.

A diverse range of soil-based stormwater control measures such as filter strips and swales, infiltration systems, storage facilities (e.g., detention basins, retention ponds and wetlands), filtration systems (storm filter) and porous pavement have been widely used to reduce the adverse hydrological and ecological impacts on receiving waters [11,12]. However, some of these treatment technologies are not effective for the removal of dissolved pollutants, spatially too limited or usually suffer from early clogging [2,13]. Stormwater infiltration/filtration systems that utilize granular adsorptive filter media enabling high infiltration rates, which can be retrofitted in small compact systems, are receiving increasing interest due to their ability to remove both dissolved and particulate pollutants [13-15]. The removal of pollutants is achieved via a number of processes including sedimentation, filtration, sorption, ion exchange, surface complexation and transformation $[5,12,16,17]$.

Studies both under laboratory $[2,5,6,13,18,19]$ and field conditions $[14,16,20]$ have investigated the ability of adsorptive filter media mixtures and soils to retain pollutants from percolating stormwater. For example, Thomas et al. [18] tested the performance of mixed filter media composed of crushed aggregate and three active ingredients: perlite, dolomite and gypsum in column experiment using synthetic stormwater reported over $90 \%$ removal efficiencies of copper and zinc. The Authors found that the media mix has an estimated lifespan of 14 to 22 years for copper and zinc loading. Bioretention systems with media mixes (sand, soil and mulch) achieved over $96 \%$ removal efficiency of oil/grease, suspended solids and $\mathrm{Pb}$ [19]. In a large-scale laboratory filter system, Reddy et al. [13] evaluated the efficiency of mixed media consisted of calcite, zeolite, sand and iron filings observed that over $90 \%$ $(\mathrm{Cd}, \mathrm{Cr}, \mathrm{Cu}, \mathrm{Pb}$ and $\mathrm{Zn})$ and $75-88 \%$ nutrients were removed from synthetic stormwater. Soil-based filters are efficient for the removal of solids, $\mathrm{Cu}, \mathrm{Ni}, \mathrm{Pb}, \mathrm{Zn}$ and PAHs [5,21]. Unfortunately, results regarding pollutant removal efficiencies, equilibrium/effluent concentrations and sorption capacities were highly variable among the studies as well as these results may not be comparable to field conditions. These variabilities could be related to many factors including single solute solution versus multi-solute solution, influent concentration, $\mathrm{pH}$, flow rate, flow direction (i.e., upflow vs. downflow mode) and filter bed height [21-24]. Column sorption experiments were mainly conducted with metal concentrations much higher than the levels in real roadway runoff waters [6,25] and also it is important to consider the simultaneous removal of co-existing metals [23]. The candidate filter media should be able to bind and adsorb multiple metals of significantly varying concentrations. In this context, the results of both laboratory $[13,21,24,26]$ and field experiments $[14,16]$ have demonstrated that soil-based and mixed media based decentralised stormwater infiltration/filtration are effective and affordable. Metals adsorbed to the filter media might not be permanently immobilized. De-icing road salts in winter periods may interfere with the operation of stormwater treatment facilities, for example the release of chemicals $[27,28]$. In column study, Norrström [28] demonstrated that a large part of $\mathrm{Pb}, \mathrm{Cd}$ and $\mathrm{Zn}$ in highway roadside soils are vulnerable to leaching when exposed to a high $\mathrm{NaCl}$ (5.84 g/L) concentration. From field studies, Bauske and Goetz [29] also found a strong effect of $\mathrm{NaCl}$ solution on $\mathrm{Cd}$ and $\mathrm{Zn}$. Additionally, studies have been conducted to examine the remobilization of heavy metals adsorbed onto filter materials used for stormwater treatment $[6,25]$. In laboratory column experiment, Huber et al. [6] have shown that pure $\mathrm{NaCl}(10 \mathrm{~g} / \mathrm{L})$ had a minor effect on the remobilization heavy metals. Recently, $\mathrm{NaCl}$ solution has been used to investigate the remobilization of previously adsorbed heavy metals, which is a crucial test criterion for the certification of filter media in Austria [30] or filtration systems in Germany [31].

Increased mobility of heavy metals coincident with road salt applications have been observed in road side soils and filter media used in stormwater filtration systems by various mechanisms, including the competition of salt derived cations with positively charged heavy metal species for sorption sites on the solid phase (ion exchange), lowered $\mathrm{pH}$, formation of chlorocomplexes and possible colloid 
dispersion $[27-29,32]$. The mobility of heavy metals induced by $\mathrm{NaCl}$ application might not behave in the same way. The mechanisms mentioned above exert their effect with different intensities depending on the heavy metal type, total amount of heavy metal present, ionic strength, hydration radius and number of electrolytes present in the system [32,33]. Filter media characteristics such as $\mathrm{pH}$, organic matter/clay content, amount and type of available charge sites and mineralogical composition are also important factors to consider when investigating metal mobility. The cations of de-icing salt are important driving forces for the mobility of heavy metals as a result of competition for adsorption sites, so that adsorbed heavy metals could be displaced from the exchange sites into solution by $\mathrm{Na}$ ions [28,32]. In the cation exchange process, selectivity of heavy metal displacement is determined by the concentration of ions, their valence, their degree of hydration and hydration radius [34]. The order of adsorption of heavy metals $\mathrm{Ni}>\mathrm{Cu}>\mathrm{Co}>\mathrm{Cd}$ coincide reasonably well with the reversed order trend of hydrated radius as $\mathrm{Cd}(4.26 \AA)>\mathrm{Co}>(4.23 \AA)>\mathrm{Cu}(4.19 \AA)>\mathrm{Ni}(4.04 \AA)$ [35]. Thus, de-icing salt is expected to have minimal effect on the mobilization of heavy metals with smaller hydration radius and higher intrinsic binding constants. Another trigger process is an increase of the ionic strength of $\mathrm{NaCl}$ promoting the release of sorbed $\mathrm{Cd}, \mathrm{Cu}, \mathrm{Pb}$ and $\mathrm{Zn}$ [33].

Results of both laboratory $[6,27,28]$ and field experiments [29] have demonstrated de-icing road salt indeed has the potential to increase metal mobility of heavy metals previously adsorbed by soil and individual (single) filter media. We hypothesised that application of de-icing road salt $(\mathrm{NaCl})$ can mobilize major parts of heavy metals previously adsorbed by mixed mineral based filter media. Consequently, the simultaneous removal of multiple heavy metals as well as the effect of de-icing salt on the mobilization of adsorbed heavy metals at experimental conditions similar to real roadway runoff were deemed necessary.

The objectives of this study were: firstly, to determine the influence of the hydraulic loading rate on simultaneous removal of $\mathrm{Cu}, \mathrm{Pb}$ and $\mathrm{Zn}$ from synthetic stormwater using five different filter media in column sorption experiments; secondly, to investigate the impact of de-icing salt $(\mathrm{NaCl})$ on the remobilization of adsorbed heavy metal; and finally, the long-term performance of each filter medium was investigated using a column breakthrough curve. To mimic heavy metal adsorption capacity at natural environmental conditions, column sorption studies were conducted with experimental conditions closer to real life of stormwater quality and treatment systems. The column study results were used to predict filter media lifespan based on effluent quality and removal efficiencies.

\section{Materials and Methods}

\subsection{Chemicals and Analytical Instruments}

All chemicals used were analytical reagent grade (Merck KGaA, Darmstadt, Germany). Synthetic stormwater solutions containing $\mathrm{Cu}, \mathrm{Pb}$ and $\mathrm{Zn}$ were prepared using analytical grade $1000 \mathrm{mg} / \mathrm{L}$ stock solutions (Titrisol ${ }^{\circledR}$, Merck, Darmstadt, Germany) of $\mathrm{CuCl}_{2}, \mathrm{~Pb}\left(\mathrm{NO}_{3}\right)_{2}$ and $\mathrm{ZnCl}_{2}$, respectively and mixed with de-ionised water to obtain the desired concentrations. The initial $\mathrm{pH}$ of the test solutions was adjusted to the desired value by using dilute solutions of $0.1 \mathrm{M} \mathrm{NaOH}$ and $65 \% \mathrm{HNO}_{3}$. Conservation of samples was performed using $1 \%$ volume of $65 \% \mathrm{HNO}_{3}$ suprapure

\subsection{Filter Media}

The performance of natural commercial available quartz sand (QS) without pre-treatment, sandy soil (SS) and three mineral-based technical filter media (TF-I, TF-II and TF-III) to remove heavy metals $(\mathrm{Cu}, \mathrm{Pb}$ and $\mathrm{Zn})$ from synthetic stormwater runoff, has been investigated through column tests. The sand soil was excavated from a newly constructed highway runoff infiltration basin and the coarse gravel fraction (dimeter over $2 \mathrm{~mm}$ ) was removed manually. There exist numerous adsorbents of different nature and they can be utilized as mixed-media filter systems. According to the ÖNORM B 2506-3 (2016) mineral-based mixture of adsorptive materials are defined as technical filter media which is here denoted as "TF". Studies showed that a combination of several filter media (for example 
zeolites, vermiculite, activated carbon, dolomite, sand and soil) are necessary to achieve effective simultaneous removal of multiple contaminants $[2,5,13,15]$. The technical filter media (TF-I, TF-II and TF-III) investigated in this study are combinations of various sorbents such as zeolite, vermiculite, dolomite, activated carbon, coconut fibre, expanded clay and soil media. All tested filter media were investigated without any physico-chemical treatment or modification. Physical characteristics and composition of the filter media are summarised in Table 1.

Table 1. Composition and physicochemical properties of filter media used in the study.

\begin{tabular}{llccccl}
\hline Filter Media & $\boldsymbol{k}_{\text {sat }}(\mathbf{m} / \mathbf{s})$ & $\mathbf{p H}(-)$ & $\mathbf{U}(-)$ & PSD $(\mathbf{m m})$ & Porosity $(\mathbf{\%})$ & \multicolumn{1}{c}{ Composition } \\
\hline QS & $3.7 \times 10^{-3}$ & 6.7 & 0.95 & $0.8(0.71-1.25)$ & 35 & Natural quartz sand \\
SS & $4.1 \times 10^{-4}$ & 8.4 & 14.3 & $3.1(0-11.2)$ & 38 & Sandy soil + gravel \\
TF-I & $1.8 \times 10^{-3}$ & 8.1 & 2.3 & $2.3(0.5-5.6)$ & 43 & Zeolite + vermiculite + crushed concrete \\
TF-II & $1.5 \times 10^{-3}$ & 8.8 & 2.1 & $2.3(0.5-5.6)$ & 39 & Zeolite + vermiculite + crushed concrete + dolomite \\
TF-III & $1.4 \times 10^{-3}$ & 8.6 & 6.7 & $1.1(0.02-4.0)$ & 41 & Zeolite + coconut fibre + expanded clay+dolomite \\
\hline
\end{tabular}

$\mathrm{PSD}=$ Particle size distribution $-\mathrm{d}_{50}$ and range; $\mathrm{U}=$ uniformity coefficient $(\mathrm{d} 60 / \mathrm{d} 10)$.

\subsection{Experimental Design}

The column experiment was carried out using two different sized columns with inner diameters of 32 and $100 \mathrm{~mm}$, respectively. The aim of the $100 \mathrm{~mm}$ column experiment was to study the efficiency of metal removal under high hydraulic loading rates. Subsequently, the effect of de-icing road salt on the mobilisation of already retained metals was studied by flushing each filter column with sodium chloride $(\mathrm{NaCl})$ solution. In the second set, continuous adsorption experiments were conducted using $32 \mathrm{~mm}$ columns to investigate the long-term capacity of the filter media to remove metals and to predict its effective lifespan.

\subsubsection{High Hydraulic Loading Conditions}

High hydraulic loading may lead to reduced stormwater retention times and could reduce treatment efficiencies. The column test was designed to simulate treatment efficiency of five different filter media at their maximum infiltration rates (saturated hydraulic conductivity, $\mathrm{K}_{\mathrm{sat}}$ ). The experiments were conducted in $800 \mathrm{~mm}$ high and $100 \mathrm{~mm}$ internal diameter (cross-sectional area of $78.5 \mathrm{~cm}^{2}$ ) plexiglass columns and an outlet diameter of $30 \mathrm{~mm}$ to allow the free flow of water by gravity. The filter media in the column was packed to the desired depth of $300 \mathrm{~mm}$, providing a filter bed volume (BV) of $2.36 \mathrm{~L}$. A drainage layer of $250 \mathrm{~mm}$ gravel $(4 / 8 \mathrm{~mm})$ and textile nylon mesh were placed at the bottom of the columns to prevent particle wash out. In order to maintain uniform feed solution distribution and flow rate, $50 \mathrm{~mm}$ gravel $(4 / 8 \mathrm{~mm})$ was placed on top of the filter media. The feed solution percolated through the filter columns in downflow mode (from top to bottom) using a precise peristaltic pump (Watson Marlon 520U, Falmouth, UK) dynamically adjusted to a flow rate that resulted in a ponding depth of $50 \mathrm{~mm}$ to elucidate peak inflow. The flow rate was 2.1, 0.225, 0.980, 0.820 and $0.770 \mathrm{~L} / \mathrm{min}$ for QS, SS, TF-I, TF-II and TF-III, respectively. For all technical filter media (TF-I, TF-II and TF-III) and QS the flow rate remained almost constant throughout the experimental period but for the column packed with sandy soil flow rate slightly reduce over time $(0.225 \mathrm{~L} / \mathrm{min}$ to $0.180 \mathrm{~L} / \mathrm{min}$ ).

The experiments were conducted in five successive runs simulating different stormwater sources and impact of de-icing salt on metal mobility (Table 2). To assess the heavy metal removal efficiency, $84 \mathrm{~L}$ of synthetic stormwater was percolated per column per experimental run (Run 1-Run 4), therefore each column received a total stormwater volume of $336 \mathrm{~L}$. After passing this volume of water, the filter columns were allowed to drain for at least $24 \mathrm{~h}$. Finally, to investigate the impact of de-icing salt on mobilization of retained metals each filter column was flushed with $42 \mathrm{~L}$ de-ionised water solution containing $5 \mathrm{~g} / \mathrm{L}$ of $\mathrm{NaCl}$ (Run 5). The concentration of $\mathrm{NaCl}$ was based on common concentrations found in urban highway runoff in Austria [36] and the Austrian Standard Method [30]. 
Table 2. Influent concentrations of heavy metals $(\mu \mathrm{g} / \mathrm{L})$ and $\mathrm{NaCl}(\mathrm{g} / \mathrm{L})$ in different experimental runs and influent $\mathrm{pH}$.

\begin{tabular}{cccccccc}
\hline \multirow{2}{*}{ Experiment } & \multicolumn{9}{c}{ Parameters and Concentration } & & \multirow{2}{*}{ pH } & Possible Source \\
\cline { 2 - 4 } & $\mathbf{C u}$ & $\mathbf{P b}$ & $\mathbf{Z n}$ & $\mathbf{N a C l}$ & & \\
\hline Run 1 & 100 & 100 & 100 & - & 5.8 & Roadways (e.g., feeder roads) \\
Run 2 & 500 & 500 & 500 & - & 5.8 & Urban highway \\
Run 3 & 3000 & 0 & 500 & - & 5.5 & Cu-roof \\
Run 4 & 150 & 0 & 5000 & - & 5.5 & Zn-roof \\
Run 5 & & & & 5 & &
\end{tabular}

Note ${ }^{1}$ The synthetic stormwater solution used first flush mean concentrations and minimum $\mathrm{pH}$ levels reported in the literature [1,22,37]; ${ }^{a}$ : Influent $\mathrm{pH}$ was not adjusted; Run 1-moderately polluted roadway runoff; Run 2-heavily polluted urban highway runoff; Run 3-copper roof runoff; and Run 4-zinc roof runoff.

The influent $\mathrm{pH}$ level (Table 2) were selected as the optimum condition, while $\mathrm{pH}$ higher than this would cause potential precipitation within the storage tank. Influent water samples were taken at the beginning of every experimental run while effluent samples were collected after every flow through of $28 \mathrm{~L}$ from each column (i.e., 3 effluent samples per experimental run per column) and analysed for dissolved concentrations of $\mathrm{Cu}, \mathrm{Pb}$ and $\mathrm{Zn}$. For the experiments with $\mathrm{NaCl}$ solution, one influent sample at the start of the experiment and several effluent samples at designated time intervals were collected in $100 \mathrm{~mL}$ glass bottles and preserved with $1 \%$ volume of $65 \% \mathrm{HNO}_{3}$. In addition, a mixed sample was collected from total effluent volume of each column. Remobilized metal mass was determined based on the effluent concentrations and effluent volume.

\subsubsection{Column Breakthrough Experiments}

Breakthrough curves of $\mathrm{Cu}, \mathrm{Pb}$ and $\mathrm{Zn}$ using five filter media were studied in small-scale plexiglass columns with an inner diameter of $32 \mathrm{~mm}$ and a length of $300 \mathrm{~mm}$. The filter media was packed to a depth of $200 \mathrm{~mm}$ (yielding a bed volume of $160 \mathrm{~mL}$ ) and used for the continuous flow test. A $20 \mathrm{~mm}$ layer of glass beads was placed at the bottom and top of the packed filter column to support the filter media and to ensure uniform flow distribution. The ratio of the inner diameter to mean particle diameter $\left(\mathrm{d}_{50}\right)$ was at least 10:1 in which wall effect can be negligible [38]. After packing, each column was slowly flushed with approximately 20 bed volumes (BV) of de-ionized water in an upflow mode in order to saturate the filter media and remove the air bubbles entrapped in the sorbent pores to maintain identical experimental conditions.

The column breakthrough experiment was devoted to urban highway runoff, where the target heavy metal concentrations were assumed to be $50 \mu \mathrm{g} / \mathrm{L} \mathrm{Pb}, 100 \mu \mathrm{g} / \mathrm{L} \mathrm{Cu}$ and $400 \mu \mathrm{g} / \mathrm{L} \mathrm{Zn}$ at an influent $\mathrm{pH}$ of $5.8 \pm 0.20$ based on a stormwater quality reviews [1,37]. The influent solution was prepared in an aquarium tank and pumped in up-flow mode (from bottom to top) using a high precision peristaltic pump (Ismatec IDEX, Laboratoriumstechnik GmbH, Wertheim, Germany). The flow rates were $50 \%$ of the flow determined at saturated hydraulic conductivity $\left(\mathrm{K}_{\text {sat }}\right)$ each filter media. Thus, the flow rate was different for each filter media. Firstly, the effect of flow mode on heavy metal removal was examined by conducting column experiment in upflow and downflow mode operated in parallel using TF-II, while maintaining all other experimental conditions constant. Finally, the sorption capacity of all five filter media was evaluated in the upflow mode and their lifespan was predicted using the maximum sorption capacity at filter media exhaustion. The experiments were performed from Monday to Friday, thus during weekends, the filter media were closed and kept saturated without flow in order to maintain similar experimental boundary conditions. The volume of solution kept closed in the filter column over the weekend was insignificant $(<<1 \%)$ compared to the total flow though volume. Effluent samples were collected in $100 \mathrm{~mL}$ glass bottles from the exit of the column at different intervals, preserved with $1 \%$ volume of $65 \% \mathrm{HNO}_{3}$ and analysed for dissolved concentrations of $\mathrm{Cu}, \mathrm{Pb}$ and $\mathrm{Zn}$. 


\subsection{Operation Criteria}

In Austria, purified wastewater should fulfil the criteria of Groundwater Quality Ordinance (QZV) of $9 \mu \mathrm{g} / \mathrm{L} \mathrm{Pb}$ and $1800 \mu \mathrm{g} / \mathrm{L} \mathrm{Cu}$ [39] and the criteria of the ÖNORM B 2506-3 [30]. Therefore, the operation target of all filter columns was terminated (i.e., filter media exhaustion) when: either $\mathrm{Pb}$ concentration in the effluent exceeded $9 \mu \mathrm{g} / \mathrm{L}$, the $\mathrm{Cu}$ removal rate fall below $80 \%$, Zn removal rate fall below $50 \%$ or a combination of these criteria.

The expected lifespan (years) of each filter media was determined by dividing the cumulative adsorbed mass of a heavy metal at filter media exhaustion point (Section 2.3.2) by the annual load of a heavy metal entering the treatment systems. The annual heavy metal loads entering the treatment systems were calculated under the following assumptions: a filter area of $8.04 \mathrm{~cm}^{2}$, a filter media depth of $300 \mathrm{~mm}$, annual precipitation of $700 \mathrm{~mm}$, dissolved runoff concentrations $25 \mu \mathrm{g} / \mathrm{L} \mathrm{Pb}, 50 \mu \mathrm{g} / \mathrm{L}$ $(\mathrm{Cu})$ and $200 \mu \mathrm{g} / \mathrm{L}(\mathrm{Zn})$ respectively which corresponds to $50 \%$ of the total concentration and size of stormwater treatment system relative to its impervious catchment area. The size of the stormwater infiltration systems relative to its impervious catchment area was estimated from the cumulative heavy metal load retained in the filter column.

\subsection{Analytical Procedures}

All samples were filtered through a $0.45 \mu \mathrm{m}$ pore size non-sterile Phenex-RC $26 \mathrm{~mm}$ syringe filter (Phenomenex LTD, Aschaffenburg, Germany) for analysing dissolved metal concentrations and was preserved with $1 \%$ volume of $65 \% \mathrm{HNO}_{3}$ until analysis. $\mathrm{Cu}, \mathrm{Pb}$ and $\mathrm{Zn}$ concentrations were measured using inductively coupled plasma mass spectrometry (ICP-MS) according to DIN EN ISO 17294-2. The detection limits were 1.0, 0.5 and 3.0 $\mu \mathrm{g} / \mathrm{L}$ for $\mathrm{Cu}, \mathrm{Pb}$ and $\mathrm{Zn}$, respectively. For simplicity, effluent concentrations below detection limit were set equal to the detection limit, recognising that this conservative assumption might underestimate the $\mathrm{Cu}, \mathrm{Pb}$ and $\mathrm{Zn}$ removals by only $1.0 \%$. The $\mathrm{pH}$ was measured immediately after sample collection using a glass electrode (WTW pH 197i, Weilheim, Germany) according to DIN EN ISO 10523-C5.

\subsection{Data Analysis}

Metal removal efficiency for a sample taken at time $t$ over the course of the experiment was calculated as follows (1):

$$
\eta_{t}(\%)=\frac{\left(C_{i t}-C_{e t}\right)}{C_{i}}
$$

where influent and effluent concentrations $(\mu \mathrm{g} / \mathrm{L})$ are denoted as $C_{i t}$ and $C_{e t}$ respectively and $\eta$ is metal removal efficiency (\%) of a sample taken at time $t$.

Influent metal load applied to each column till media exhaustion or termination of the experiment, (mg), was calculated as follows (2)

$$
q_{i}=\frac{\sum\left(C_{i} * V_{i}\right)}{1000}
$$

where $C_{i}$ is the influent concentration $(\mu \mathrm{g} / \mathrm{L})$ and $V_{i}$ is influent volume passed through the filter column (L)

Mass of metal adsorbed till filter media exhaustion or termination of the experiment, $q_{s}(\mathrm{mg})$, was calculated using Equation (3):

$$
q_{s}=\frac{\sum\left(C_{i} * V_{i}\right)-\sum\left(C_{e} * V_{e}\right)}{1000}
$$

where $C_{i}$ and $C_{e}$ are the influent and effluent concentration $(\mu \mathrm{g} / \mathrm{L})$ and $V_{i}$ and $V_{e}$ influent and effluent volumes (L). 
Heavy metal adsorption capacity $\left(q_{e}\right)$ at column exhaustion or at the end of four successive dosing of synthetic stormwater (Run 1-4), simulating different runoff sources per unit dry weight of filter media packed in the column, (mg/g), was calculated using the following Equation (4):

$$
q_{e}=\frac{q_{s}}{M}
$$

where $M(\mathrm{~g})$ the total dry weight of filter media packed in the column.

\section{Results and Discussions}

\subsection{Effluent $p H$ Variations during the Experiments}

Although the $\mathrm{pH}$ of the feed multi-metal solution was adjusted to $5.8 \pm 0.2$ during all column experimental runs, the effluent $\mathrm{pH}$ was higher than the influent for all tested filter media (Figure 1). Effluent $\mathrm{pH}$ exhibited a general decreasing trend over the course of the experimental period for all columns, decreasing from 8.6 to 7.1 for TF-I, 9.1 to 7.9 for TF-II, 9.1 to 7.8 for TF-III, 9.2 to 7.9 for SS and 6.7 to 5.6 for QS, respectively. At the end of the experiments the effluent $\mathrm{pH}$ of the columns packed with soil based and mineral-based technical filter media remained consistently high ranging from 7.1 to 8.0. However effluent $\mathrm{pH}$ of the QS column dropped from 6.7 to 5.6.

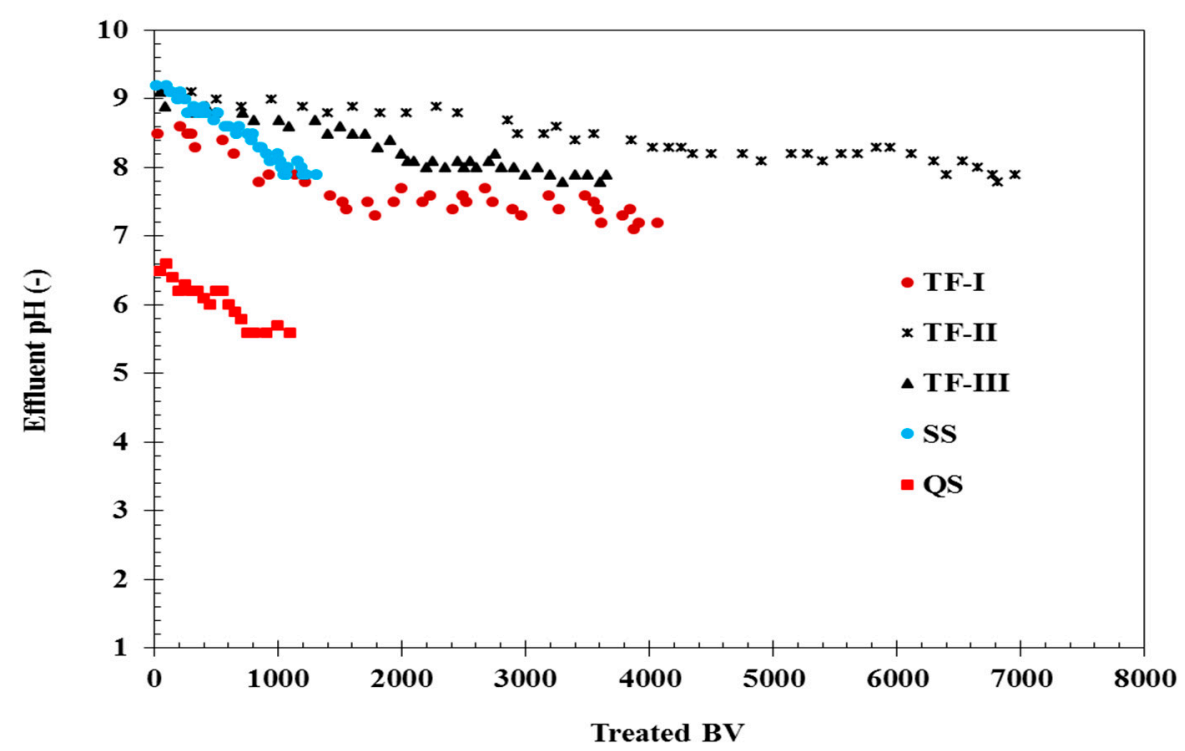

Figure 1. $\mathrm{pH}$ drift curves for column experiments conducted at influent $\mathrm{pH}$ value of $5.8 \pm 0.2$.

The increase in $\mathrm{pH}$ suggested that the soil and technical filter media have good $\mathrm{pH}$ buffering capacity. The higher effluent $\mathrm{pH}$ observed in the technical filter media packed columns was mainly due to calcite (dolomite) additive as an additional amendment in the mixed media. The dissolution of the carbonate phase, impurities present in the filter media, adsorption of hydrogen ions from the solution as well as cationic exchange causes a rapid increment of $\mathrm{pH}$ in the solid-water interface $[4,13,17,40]$. According to the ÖNORM B2506-3 [30] in column experiments with $100 \mathrm{~mm}$ inner diameter (2.36 L bed volume) a filter media should achieve a minimum effluent $\mathrm{pH}$ of $6.0 \pm 0.1$ while it is flushed with influent $\mathrm{pH}$ of $3.0 \pm 0.1$ at a flow rate that produces $5 \mathrm{~cm}$ ponding level for at least half an hour for filter media with $k_{\text {sat }}$ over $2.5 \times 10^{-3} \mathrm{~m} / \mathrm{s}$ or a minimum flow through of $42 \mathrm{~L}$ when $k_{\text {sat }}$ is below $2.5 \times 10^{-3} \mathrm{~m} / \mathrm{s}$. In this regard, the investigated technical filter media and sandy soil are suitable for utilization in stormwater filtration/infiltration systems but QS failed to meet the minimum requirements. 


\subsection{Effect of High Hydraulic Load}

The effect of hydraulic load on the adsorption of the selected heavy metals was carried out with synthetic stormwater solutions representing first-flush highway and roof runoff (Table 2). As shown in Figure 2, effluent heavy metal concentration trends suggest that the soil and technical filter media were able to maintain high removal performance for all experimental runs (Run 1-Run 4). For the soil and technical filter media effluent $\mathrm{Pb}$ and $\mathrm{Cu}$ concentrations were below the maximum allowed $(9 \mu \mathrm{g} / \mathrm{L}$ for $\mathrm{Pb}$ and $1800 \mu \mathrm{g} / \mathrm{L}$ for $\mathrm{Cu})$ and the required minimum removal efficiencies $(80 \%$ for $\mathrm{Cu}$ and $50 \%$ for $\mathrm{Zn}$ ) were reached during the whole experimental period. As can be seen in Figure 2, the influent heavy metal concentration had a minor influence on treatment performance of sandy soil and technical filter media. The QS filter column managed to effectively remove all three heavy metals from the synthetic highway runoff (Run 1 and Run 2), however for experiments with synthetic roof runoffs (Run 3 and Run 4) effluent concentration of $\mathrm{Cu}$ as well as removal efficiencies of $\mathrm{Cu}$ and $\mathrm{Zn}$ were not met. It should be mentioned that the natural quartz sand (QS) turned out to contain some metal iron impurities, which could potentially serve as adsorption sites for heavy metal ions through surface complexes on iron oxyhydroxides. Metal ions that form outer-sphere complexes are readily exchangeable and are expected to be more easily displaced from the adsorbent surface [41]. For the experiment with zinc roof runoff (Run 4), effluent concentrations of $\mathrm{Cu}$ were significantly higher than its inlet concentration $(150 \mu \mathrm{g} / \mathrm{L})$ and exceeded the required levels of $1800 \mu \mathrm{g} / \mathrm{L}$ [39]. This phenomenon was due to the displacement of weakly adsorbed $\mathrm{Cu}$ from previous dosings (Run 1-Run 3) in favour of the increased $\mathrm{Zn}$ influent concentration. The displacement of $\mathrm{Cu}$ can also be related to the relatively low influent $\mathrm{pH}$, strength of complexation and adsorption order. The extent of simultaneous adsorption of heavy metals is influenced by adsorbate concentration and presence of competing metal ions [23]. This competitive adsorption also showed that adsorption of $\mathrm{Cu}$ decreased significantly when high concentration of $\mathrm{Zn}$ was added in the influent. The effect competitive heavy metal ions on adsorption efficiency was more pronounced in the QS filter column. For example, in the experiment with copper roof runoff (Run 3), effluent $\mathrm{Cu}$ concentration reached $70 \%$ of the inlet concentration while the effluent $\mathrm{Zn}$ concentration reached $100 \%$ of its inlet concentration $(500 \mu \mathrm{g} / \mathrm{L})$. Accordingly, $\mathrm{Cu}$ outcompetes $\mathrm{Zn}$ in occupying available sorption sites of QS. This is in agreement with the findings of Atanassova [42], that in a multi-component system, an increase in the Cu concentration reduced the uptake of other heavy metals such as $\mathrm{Ni}, \mathrm{Cd}$ and $\mathrm{Zn}$.

In general, subsequent dosings of the columns with synthetic runoff showed that the soil and technical filter media were able to remove the heavy metals, thus significantly reducing the concentrations of $\mathrm{Cu}, \mathrm{Pb}$ and $\mathrm{Zn}$ (Figure 2). The extent of heavy metal removal depends on the initial heavy metal concentration and filter media type or composition $[4,24]$. The performance of each filter media in reducing the heavy metal levels was assessed based on the influent and effluent concentrations. All filters removed more than $98 \%$ of $\mathrm{Pb}$. The mean removal efficiency of $\mathrm{Cu}$ was $89.6 \%, 97.4 \%, 98.5 \%$ and $90.5 \%$ through the filter columns packed with SS, TF-I, TFII and TF-III, respectively. The mean removal efficiency of $\mathrm{Zn}$ was $93.4 \%, 96.6 \%, 98.7 \%$ and $89.2 \%$ through the filter columns packed with SS, TF-I, TFII and TF-III, respectively. The results indicated that the mean removal efficiencies of $\mathrm{Cu}$ and $\mathrm{Zn}$ by the sandy soil and technical filter media are not statistically different. Nevertheless, it seemed that the composition of the studied technical filter media has played an important role in treatment efficiency. The mineral composition of TF-I and TF-II were similar, except for the $3 \%$ dolomite in the case of TF-II. However, the technical filter media with dolomite (TF-II) provided the best treatment performance indicating that carbonate content enhanced the removal of the studied metals. 


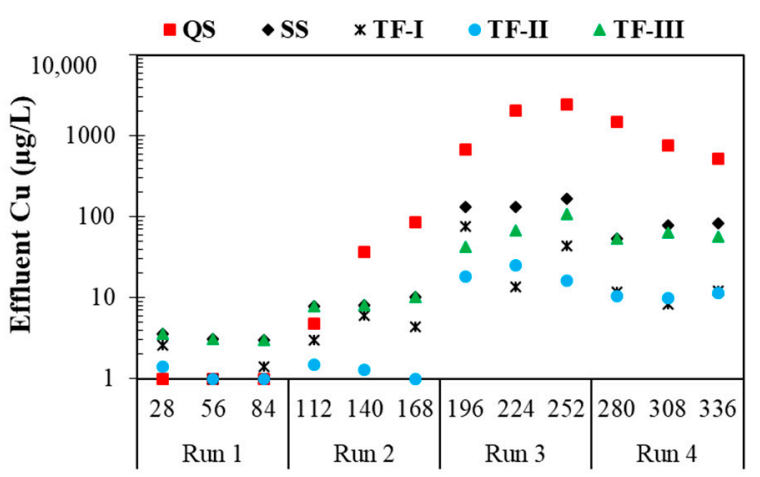

Influent volume (L) and experimental run

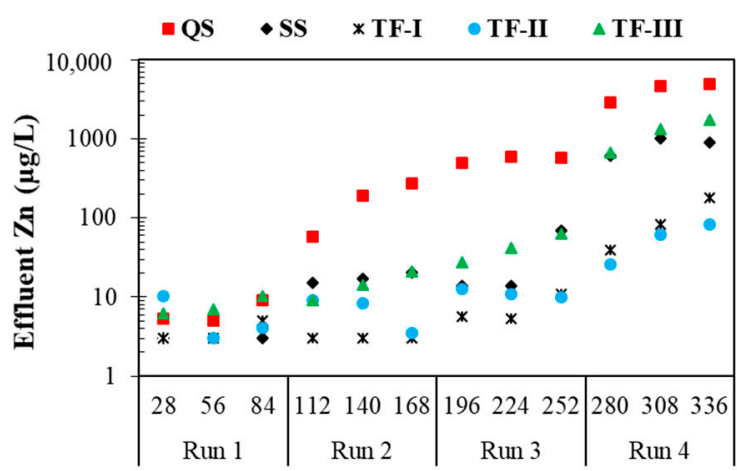

Influent volume $(L)$ and experimental run

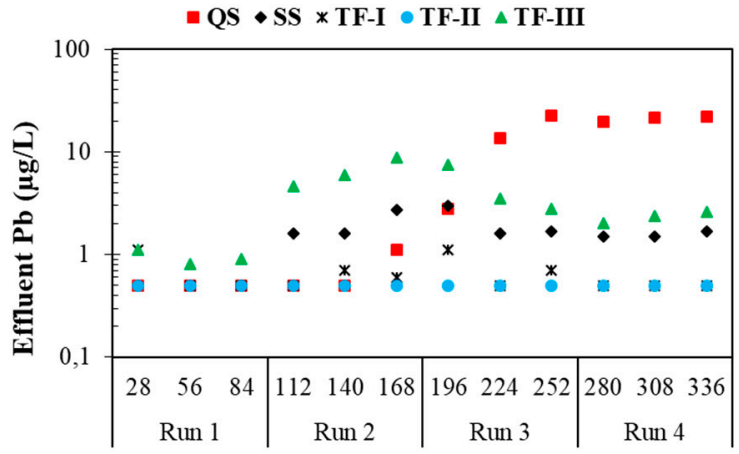

Influent volume (L) and experimental run

Figure 2. Effluent concentrations of heavy metals with different synthetic stormwater dosings (Run 1-Run 4, see Table 2) under high hydraulic load experimental conditions as a function of treated volume.

Overall cumulative metal removal efficiency of each filter media was determined using the total influent and effluent loads (Run 1-Run 4). The results of the calculated cumulative removal efficiencies and the corresponding adsorption capacity are presented in Figure 3 and the influent load added to each column was $51.8 \mathrm{mg}$, 334.6mg and $542.9 \mathrm{mg}$ for $\mathrm{Pb}, \mathrm{Cu}$ and $\mathrm{Zn}$, respectively. Load removal efficiencies through the soil based and technical filter media (SS, TF-I, TF-II and TF-III) were $>95 \%$ for $\mathrm{Cu}$ and $\mathrm{Pb}$ and more that $87 \%$ for $\mathrm{Zn}$. These results demonstrate that all filter media were effective for the simultaneous removal of heavy metals, except for QS which had significantly lower removal efficiency of $\mathrm{Cu}$ and $\mathrm{Zn}$. It is important to note that results presented in Figure 3 refers only to the adsorbed amount following four successive dosing of synthetic stormwater (Run 1-Run 4) simulating different runoff sources are not the maximum the adsorption capacities. Adsorption capacity was in the order of $\mathrm{Pb}<\mathrm{Cu}<\mathrm{Zn}$ which coincide well with the order trend of the influent load (influent concentration). The increase in adsorption capacity with increasing heavy metal influent load is due to the increase in the driving force for mass transfer as well as an increase in electrostatic interactions (physical adsorption relative to covalent interactions) [35]. Despite its high removal efficiency, adsorption capacity of $\mathrm{Pb}$ was lowest. This is attributed to its very low influent load compared to $\mathrm{Cu}$ and $\mathrm{Zn}$. Similar to our findings, Hatt et al. [2,5] showed that a wide range of media compositions (i.e., combinations of sand, sandy loam, vermiculite, perlite, compost, mulch, charcoal) achieved more than $90 \%$ removal of $\mathrm{Cu}, \mathrm{Pb}$ and $\mathrm{Zn}$ from synthetic stormwater. Results indicated that the natural quartz sand (QS) has lowest sorption capacity compared to soil based and technical filter media which is attributed to its low surface area and few sorption sites [4,6,24]. 


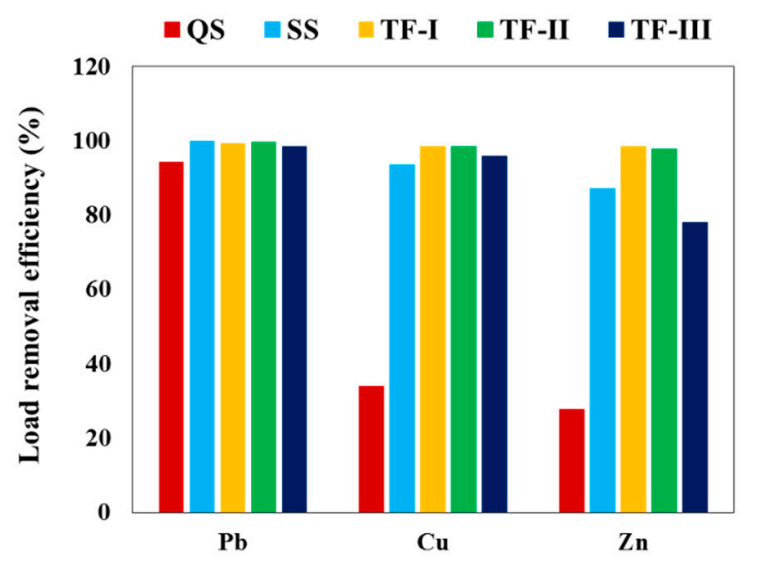

Heavy metal

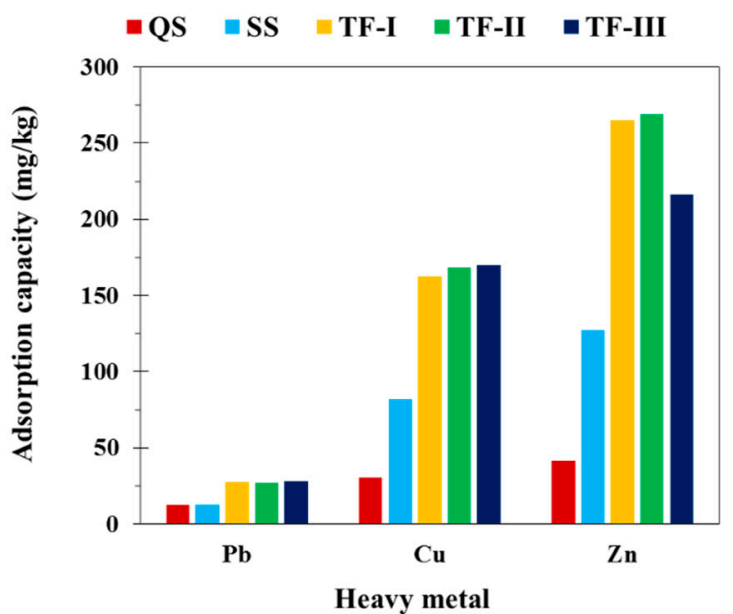

Heavy metal

Figure 3. Overall removal efficiency (left) and adsorption capacity (right) of heavy metals by each filter media type following four successive runs (Run 1-Run 4) simulating different stormwater sources.

\subsection{Remobilization of Heavy Metals}

Table 3 shows the mean and range of heavy metal concentrations measured at the effluent after each column was flushed with $5 \mathrm{~g} / \mathrm{L} \mathrm{NaCl}$ solution. Heavy metals were remobilized with different intensities depending on metal and filter media type. Regardless of the filter media type, concentrations of mobilized heavy metals were in the order of $\mathrm{Zn}>\mathrm{Cu}>\mathrm{Pb}$, which coincide well with the order trend of adsorbed mass. Effluent concentrations of metals measured after the passage of one bed volume were higher but decreased successively over time with continued flushing. This suggested that precipitated or slightly adsorbed fractions of the retained metals were remobilized easily during the initial passage of $\mathrm{NaCl}$ solution. As displayed in Table 3, the de-icing salt $(\mathrm{NaCl})$ solution had similar effects on the soil based and technical filter media and the three metals. Except for effluents from QS, remobilizations of metals were low and comply with the requirements noted in the ÖNORM B 2506-3 [30]. This relative low release indicates that adsorption was stable and salts would not have a major influence on the remobilization of previously retained metals. However, the heavy metals that had retained in the QS filter column were released in highest amounts indicating a major effect of $\mathrm{NaCl}$ so that this filter media is not feasible for utilization in stormwater filtration systems. The main metal removal mechanism by QS is outer-sphere complexation or non-specific electrostatic adsorption to negatively charged functional group sites on the sand particle surfaces.

Table 3. Remobilization of previously adsorbed metals during road de-icing salt application (42 L solution of $5 \mathrm{~g} / \mathrm{L} \mathrm{NaCl}$ ). Mean effluent metal concentrations are indicated in bold numbers and the Italic values in bracket are ranges.

\begin{tabular}{ccccccc}
\hline $\begin{array}{c}\text { Heavy } \\
\text { Metal }\end{array}$ & TF I & TF-II & TF-III & SS & QS & $\begin{array}{c}\text { ÖNORM B } \\
\text { 2506-3 (2016) }\end{array}$ \\
\hline $\mathrm{Pb}$ & $\mathbf{4 . 2 ( 3 . 1 - 7 . 3 )}$ & $\mathbf{3 . 3 ( 2 . 7 - 5 . 4 )}$ & $\mathbf{6 . 4}(2.7-13.9)$ & $\mathbf{3 . 6}(2.7-5.9)$ & $\mathbf{8 3}(63.2-203)$ & $\mathbf{9}$ \\
$\mathrm{Cu}$ & $\mathbf{8 . 6 ( 5 . 1 - 2 4 )}$ & $\mathbf{6 . 8}(4-17.9)$ & $\mathbf{2 0 . 3 ( 1 3 . 8 - 3 9 )}$ & $\mathbf{7 . 0 ( 4 - 1 5 . 8 )}$ & $\mathbf{1 2 7}(43-305)$ & $\mathbf{5 0}$ \\
$\mathrm{Zn}$ & $\mathbf{2 3 . 7 ( 1 2 - 4 7 )}$ & $\mathbf{1 7 . 3 ( 1 2 - 3 7 )}$ & $\mathbf{1 6 0}(121-186)$ & $\mathbf{1 6 . 5}(12-30)$ & $\mathbf{8 2 5}(676-1377)$ & $\mathbf{5 0 0}$ \\
\hline
\end{tabular}

The mass and load fractions of each heavy metal remobilized from the filter columns as compared to the total mass previously retained by each filter media are presented in Table 4. As shown in Table 4, the effect of $\mathrm{NaCl}$ application was more pronounced for QS. The results showed that an extensive mobilization of heavy metals from the QS column $(5.4 \% \mathrm{Cu}, 6.8 \% \mathrm{~Pb}$ and $22 \%$ of $\mathrm{Zn}$ the total retained) occurred in response to $\mathrm{NaCl}$ application. Conversely, only a small fraction $(<2.0 \%)$ of the retained heavy metals were mobilized from the soil and technical filter media. This implies 
that chemisorption was the principal metal removal mechanism and salts would not have a major effect on metal mobilization. Our study concluded that mobilization of $\mathrm{Cu}, \mathrm{Pb}$ and $\mathrm{Zn}$ from the technical filter media (TF-I, TF-II and TF-III) and sandy soil (SS) in response to $\mathrm{NaCl}$ application, though not alarming, is more likely due to the combined effect of cation exchange and complexation with chloride. Similar results were reported from column studies using alternative filter media other than soil for treatment of highway runoff [6,25]. Monrabal-Martinez et al. [25] observed a small release of $\mathrm{Cd}, \mathrm{Cu}, \mathrm{Pb}$ and $\mathrm{Zn}(<3 \%)$ by $\mathrm{NaCl}$ from filter columns (pine bark, olivine and charcoal) preloaded with about $50 \mathrm{mg}$ of each metal. Conversely, other studies with soils containing 17-50\% clay reported an extensive remobilisation of heavy metals as a result of exposure to high concentration of $\mathrm{NaCl}[27,28,32]$. This could be attributed to the fact $\mathrm{NaCl}$ promotes the dissolution of organic matter and/or clay which favours mobilization of heavy metals. Mechanisms of metal mobilization were association with coagulated or sorbed organic matter in combination with colloid dispersion, chloride complexation and ion exchange. Norrström [28] evaluated the impact of de-icing salt on remobilization of $\mathrm{Cd}, \mathrm{Cu}, \mathrm{Pb}$ and $\mathrm{Zn}$ from soils collected from two highway runoff infiltration trenches $(1.5-2.7 \mathrm{mg} / \mathrm{kg}$ $\mathrm{Cd}, 155-194 \mathrm{mg} / \mathrm{kg} \mathrm{Cu}, 171-324 \mathrm{mg} / \mathrm{kg} \mathrm{Pb}$ and $607-781 \mathrm{mg} / \mathrm{kg} \mathrm{Zn)}$. They reported that 37-45\% of Cd, $0.1-0.2 \%$ of $\mathrm{Pb}$ and $4.7-5.0 \%$ of $\mathrm{Zn}$ were leached by $\mathrm{NaCl}$.

Table 4. Heavy metals adsorption and their remobilization/desorption using $42 \mathrm{~L}$ solution of $5 \mathrm{~g} / \mathrm{L} \mathrm{NaCl}$.

\begin{tabular}{cccccccccc}
\hline \multirow{2}{*}{ Filter Media } & \multicolumn{3}{c}{ Adsorbed Mass (mg) } & \multicolumn{3}{c}{ Remobilized Mass (mg) } & \multicolumn{3}{c}{ Remobilized Fraction (\%) } \\
\cline { 2 - 10 } & $\mathbf{P b}$ & $\mathbf{C u}$ & $\mathbf{Z n}$ & $\mathbf{P b}$ & $\mathbf{C u}$ & $\mathbf{Z n}$ & $\mathbf{P b}$ & $\mathbf{C u}$ & $\mathbf{Z n}$ \\
\hline QS & 48.6 & 98.5 & 157 & 2.8 & 2.3 & 25.2 & 6.8 & 5.4 & 22 \\
SS & 52.1 & 303 & 526 & 0.15 & 0.29 & 0.86 & 0.29 & 0.1 & 0.16 \\
TF-I & 51.9 & 342 & 507 & 0.18 & 0.36 & 1 & 0.34 & 0.11 & 0.20 \\
TF-II & 49.8 & 342 & 542 & 0.13 & 0.29 & 0.95 & 0.26 & 0.08 & 0.18 \\
TF-III & 54.6 & 309 & 393 & 0.28 & 0.85 & 12.6 & 0.51 & 0.28 & 1.7 \\
\hline
\end{tabular}

Remobilization of heavy metals is a function of several mechanism including cation exchange, colloid dispersion, chloride complex formation, metal characteristics and total concentration of metals in the media $[27,28,32]$. Overall, results of the present study indicated that the heavy metals $(\mathrm{Cu}$, $\mathrm{Pb}$ and $\mathrm{Zn}$ ) are strongly attached to the soil and technical filter media.

\subsection{Effect of Flow Mode on Heavy Metal Removal}

The breakthrough curves for $\mathrm{Cu}, \mathrm{Pb}$ and $\mathrm{Zn}$ removal at two different flow modes are shown in Figure 4. It has been observed that heavy metal removal efficiencies in the upflow mode were generally high as compared to the downflow mode. As shown in Figure 4 both the shape and gradient of the breakthrough curves were different with variations in flow direction. The breakthrough point for $\mathrm{Cu}$ and $\mathrm{Zn}$, set at $\mathrm{Ce} / \mathrm{C}_{i}=10 \%$, was almost $2300 \mathrm{BV}$ for the downflow mode and $7600 \mathrm{BV}$ for the upflow mode. At 20\% breakthrough of Cu 9700 BV of synthetic stormwater was treated by TF-II operated in the upflow mode and the requirements of the Austrian regulation regarding $\mathrm{Pb}$ maximum effluent concentration of $9 \mu \mathrm{g} / \mathrm{L}$ and $\mathrm{Zn}$ minimum removal efficiency of $50 \%$ were met. Accordingly, exhaustion (lifespan) of the filter media (TF-II) was limited by $\mathrm{Cu}$ removal. The corresponding adsorption capacities of TF-II at the $20 \%$ breakthrough point of $\mathrm{Cu}$ were $573.8 \mathrm{mg} / \mathrm{kg}, 1182 \mathrm{mg} / \mathrm{kg}$ and $4669 \mathrm{mg} / \mathrm{kg}$ for $\mathrm{Pb}, \mathrm{Cu}$ and $\mathrm{Zn}$ respectively. On the contrary, in the downflow mode $20 \%$ breakthrough of $\mathrm{Cu}$ was achieved at $7100 \mathrm{BV}$ and exhaustion (lifespan) of the filter media was limited by $\mathrm{Cu}$ removal at nearly $7100 \mathrm{BV}$. The sorption capacity at exhaustion point was $447 \mathrm{mg} / \mathrm{kg}, 771 \mathrm{mg} / \mathrm{kg}$ and $2771 \mathrm{mg} / \mathrm{kg}$ for $\mathrm{Pb}, \mathrm{Cu}$ and $\mathrm{Zn}$ respectively. Similar to our findings, a short breakthrough time and low adsorption capacity of metal ions was reported for a downflow mode as compared to the upflow mode [22,43]. For example, Athanasiadis [22] reported that the adsorption capacity of clinoptilolite 
for $\mathrm{Cu}$, obtained at breakthrough point $\left(C_{e} / C_{i}=10 \%\right)$, was $1144 \mathrm{mg} / \mathrm{kg}$ for the downflow mode and $1906 \mathrm{mg} / \mathrm{kg}$ for the upflow mode, respectively.
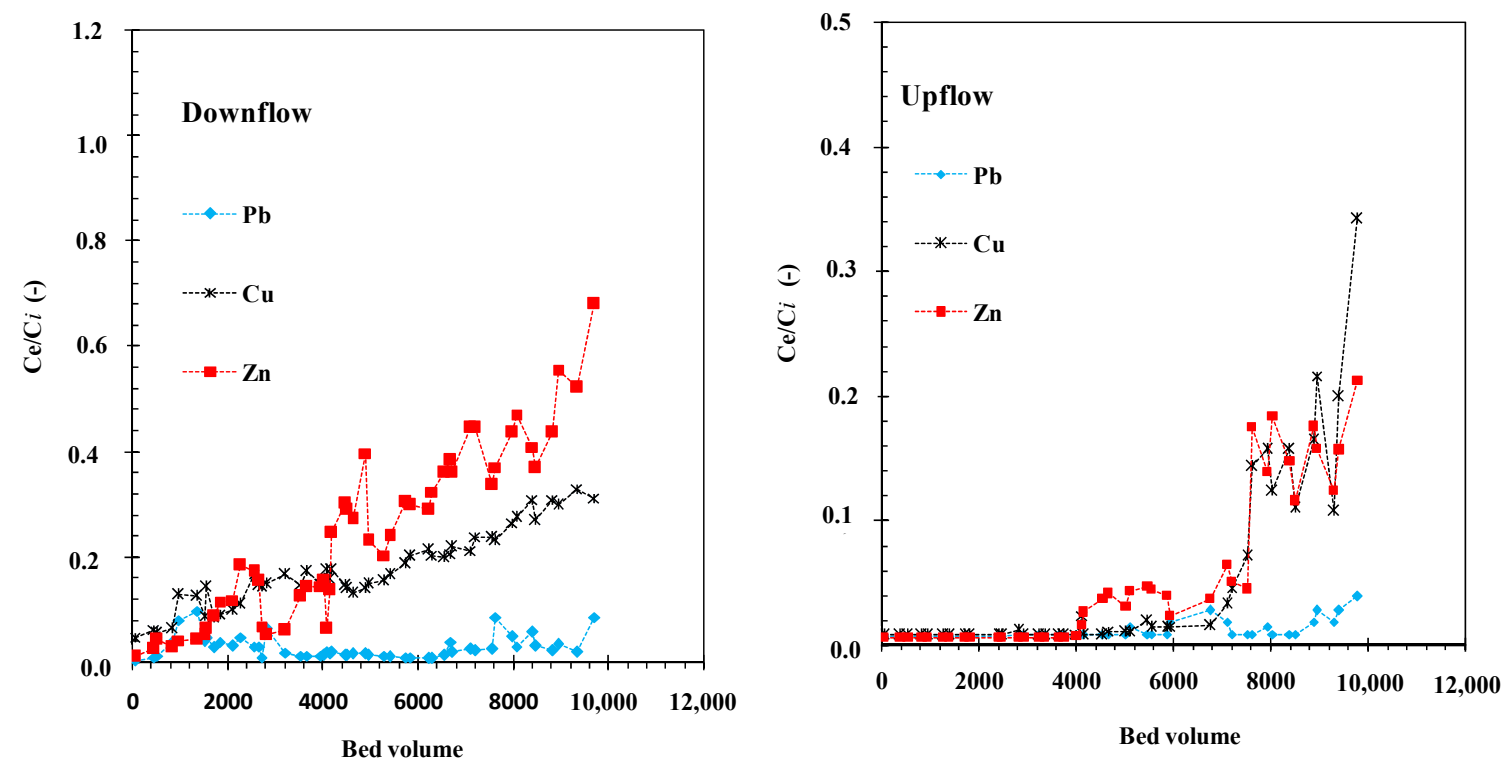

Figure 4. Comparison of breakthrough curves of $\mathrm{Cu}, \mathrm{Pb}$ and $\mathrm{Zn}$ in downflow and upflow mode as a function of bed volume at a volumetric flow rate of $50 \mathrm{~mL} / \mathrm{min}(50 \%$ of its maximum saturated flow rate) and filter bed volume of $160 \mathrm{~mL}$. Note that to facilitate visibility of the graph, the Y-axis is different in each case.

The observed performance difference between the downflow and the upflow mode is explained by variabilities in the liquid holdups and liquid maldistribution [43]. The upflow mode allows saturation of all the vacant metal binding sites which leads to the achievement of higher equilibrium sorption process. These differences are attributed to the liquid holdup in the upflow mode is $100 \%$, while for the downflow mode liquid holdup time is only a function of volumetric flow rate. Furthermore, feeding the multi-metal solution in the upflow mode ensures saturated flow conditions and uniform hydraulic distribution of the sorbate. Accordingly, under the same experimental conditions it becomes apparent that the upflow mode resulted in a more effective use of the filter media. Results of the present study demonstrated that the upflow mode was more efficient in maintaining a saturated flow through condition leading to higher sorption capacity. Therefore, to predict the life span of filter media based on sorption capacity, column experiment operating in upflow mode would be more appropriate.

\subsection{Breakthrough Curves}

The breakthrough curves of $\mathrm{Cu}, \mathrm{Pb}$ and $\mathrm{Zn}$ in the column experiments are presented in Figure 5. Subsequent dosing of the columns with synthetic roadway runoff showed that treatment by technical filter media (TF-I, TF-II and TF-III) and sandy soil (SS) filters are effective in removing $\mathrm{Cu}, \mathrm{Pb}$ and $\mathrm{Zn}$ simultaneously to effluent levels below analytical detection limit (i.e., $\mathrm{Ce} / \mathrm{Ci}<0.01$ ). After the breakthrough (i.e., $\mathrm{Ce} / \mathrm{Ci}=0.1$ ) metal effluent concentrations from all filter media started to increase overtime as a function of treated bed volumes. The patterns of metals breakthrough curves (Figure 5) were similar for all filter columns and the steepness of the breakthrough curves decreased in the order of $\mathrm{Pb}>\mathrm{Cu}>\mathrm{Zn}$ for all filter media. 

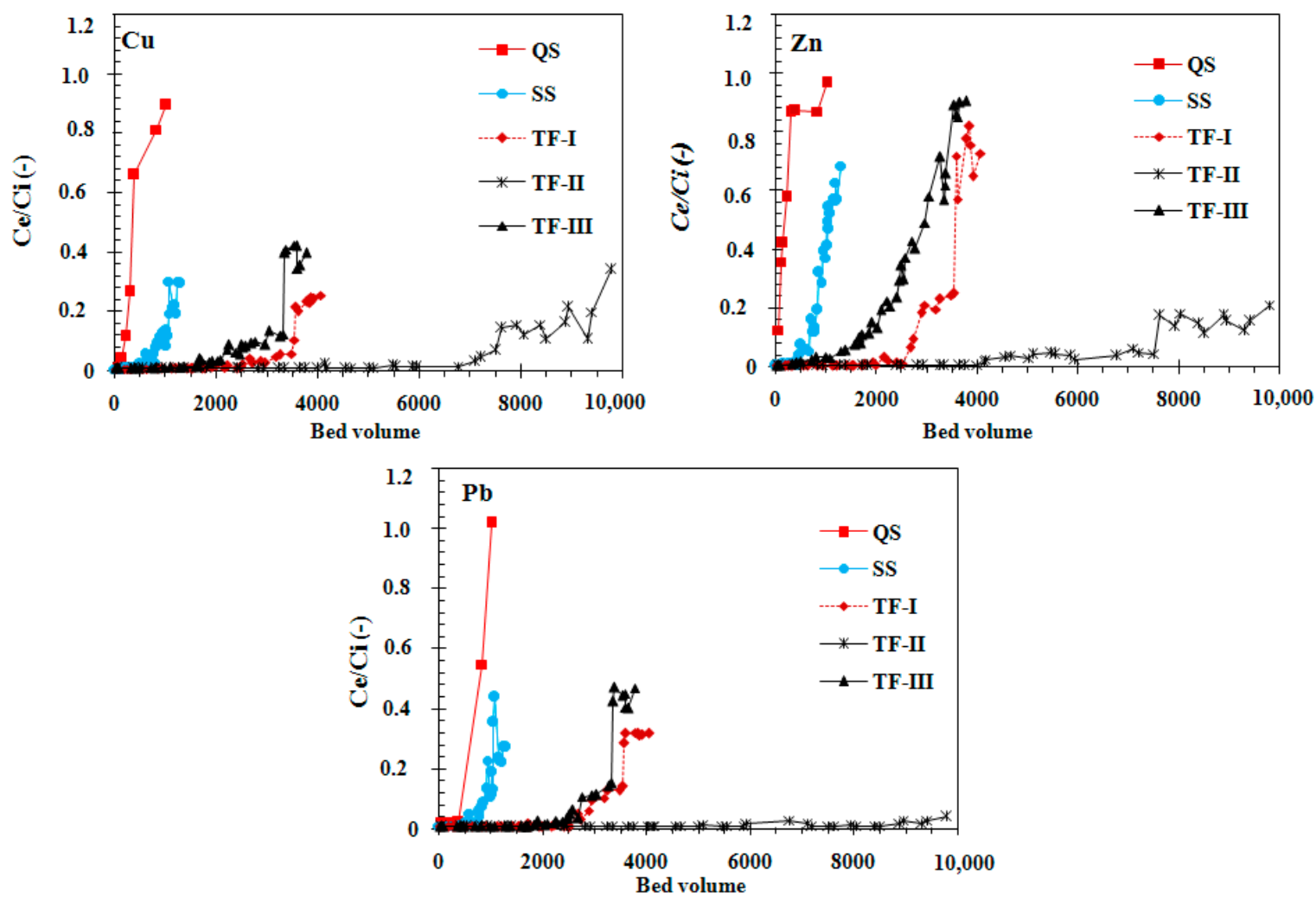

Figure 5. Breakthrough curves of column experiments for metal mixtures. The lines are not fitting functions; they simply connect points to facilitate visualization.

The volume of stormwater treated by all five filter media was different depending on the sorption capacity and total flow through volume at exhaustion. It has to be noted that TF-II treated more stormwater before breakthrough as compared to other filter media types. Zn breakthrough $(\mathrm{Ce} / \mathrm{Ci}<0.1)$ occurred in the QS filter media first, followed by SS, TF-III, TF-II and TF-II, respectively (Figure 5). The number of bed volumes to breakthrough was 55, 680, 1700, 2700 and 7600 for QS, SS, TF-I, TF-III and TF-II, respectively. Zn breakthrough generally occurred faster as compared to $\mathrm{Cu}$ and $\mathrm{Pb}$ which demonstrates that the influent metal concentration has a significant effect on breakthrough curve. This was in good agreement with earlier studies which showed $\mathrm{Zn}$ is relative mobile compared to $\mathrm{Pb}$ and $\mathrm{Cu}$ [5]. As indicated in Figure 5 full breakthrough (i.e., $\mathrm{Ce} / \mathrm{Ci}=1$ ) of $\mathrm{Pb}, \mathrm{Cu}$ and $\mathrm{Zn}$ was not observed in all filters within the experimental running time of three months, except for QS filter column.

Experimental results with the QS filter column indicated a breakthrough of $\mathrm{Cu}, \mathrm{Pb}$ and $\mathrm{Zn}$ beginning at $50 \mathrm{BV}$ and was nearly complete $\left(C e / C_{i} \approx 1.0\right)$ after a total flow though of $1000 \mathrm{BV}$. The filter column QS was found to be the worst with fair metal removal in the early dosing stages but shortly effluent concentration of $\mathrm{Pb}$ exceeded the groundwater quality criteria value of $9 \mu \mathrm{g} / \mathrm{L}$ [39]. Similar to our findings, Genc-Fuhrman et al. [4] reported that among 11 sorbents, sand has a minor efficiency for the removal of heavy metals which is attributed to its low specific surface area and cation exchange capacity. Removal of heavy metals increased with increasing $\mathrm{pH}$ by processes such as surface complexation between dissolved species and oxide and hydroxide groups [4]. The decrease in metal removal was in line with the $\mathrm{pH}$ drift curve (Figure 1). Measured effluent $\mathrm{pH}$ levels showed that QS has very limited $\mathrm{pH}$ buffering capacity, consequently its performance on heavy metal removal was very poor as compared to other filter media (i.e., SS, TF-I, TF-II and TF-III).

The filter columns packed with soil and technical filter media showed a maximum breakthrough value $\left(\mathrm{Ce} / \mathrm{C}_{i}\right)$ of around 0.3 to 0.5 for $\mathrm{Pb}$ and $\mathrm{Cu}$ and 0.21 to 0.91 for $\mathrm{Zn}$. The column data suggest that TF-II has high affinity for all tested heavy metals and the magnitude of the sorption (up to $7100 \mathrm{BV}$ ) 
remained constant with removal rates of over $93 \%$. Initial metal ion concentration has a significant effect on breakthrough time and filter media exhaustion. The breakthrough curves determined in this study were slower and least steep, thus the number of BV passed at breakthrough time reported here are much higher than those reported in other studies. It is difficult to compare these results directly to those of other investigators because the influent concentrations are often higher than the levels used in this study $[6,15,23]$.

It is possible that the adsorption capacity of the filter media may be exhausted before clogging occurs, resulting in high effluent concentrations exceeding discharge water quality and low removal efficiencies of heavy metals [5]. The effluent concentration of $\mathrm{Pb}$ was exceeding the maximum allowable of $9 \mu \mathrm{g} / \mathrm{L}$ for groundwater protection [39] after the passage of 300, 1060, 3360 and 3600 bed volumes for QS, SS, TF-I and TF-III, respectively. Comparable bed volumes were treated to reach the $20 \%$ and 50\% breakthrough of $\mathrm{Cu}$ and $\mathrm{Zn}$, respectively. On the contrary, for the filter column packed with TF-II 20\% breakthrough (80\% removal) of Cu was achieved after the passage of 97,000 BV while effluent concentration of $\mathrm{Pb}$ and $\mathrm{Zn}$ removal efficiency fulfil the requirements throughout the entire experimental duration. Therefore, lifespan of TF-II was limited by $\mathrm{Cu}$ removal and after the treatment of $9800 \mathrm{BV}$ this filter media was considered as exhausted.

The cumulative heavy metal loads applied to each column, mass retained in the filter column, cumulative load removal efficiencies and adsorption capacity at filter media exhaustion point are summarized in Table 5. Due to the differences in volumetric flow rate and the exhaustion point, the total flow though volume and total influent heavy metal loads were different for each filter. It can be seen that the influent load of individual contaminants applied into the QS and SS was significantly lower in comparison to the loads applied to the technical filter media. Nevertheless, the load removal efficiencies of each filter column were comparable. Over $90 \% \mathrm{Cu}$ and $\mathrm{Pb}$ dosed into the columns were retained in the filter media, while $\mathrm{Zn}$ removal ranged from $62.6 \%$ (QS) to $93 \%$ (TF-II).

Table 5. Removal efficiencies and sorption capacity of each filter column at filter media exhaustion for $\mathrm{Cu}, \mathrm{Pb}$ and $\mathrm{Zn}$.

\begin{tabular}{cccccccccccccc}
\hline \multirow{2}{*}{ Column } & \multicolumn{3}{c}{$\boldsymbol{q}_{\boldsymbol{i}}(\mathbf{m g})$} & \multicolumn{3}{c}{$\boldsymbol{q}_{\boldsymbol{s}}(\mathbf{m g})$} & \multicolumn{3}{c}{ Load Removal (\%) } & \multicolumn{3}{c}{$\boldsymbol{q}_{\boldsymbol{e}}$ (mg/kg) } \\
\cline { 2 - 14 } & $\mathbf{C u}$ & $\mathbf{P b}$ & $\mathbf{Z n}$ & $\mathbf{C u}$ & $\mathbf{P b}$ & $\mathbf{Z n}$ & $\mathbf{C u}$ & $\mathbf{P b}$ & $\mathbf{Z n}$ & $\mathbf{C u}$ & $\mathbf{P b}$ & $\mathbf{Z n}$ \\
\hline QS & 3.92 & 1.92 & 17.9 & 3.39 & 1.87 & 11.2 & 83.8 & 97.5 & 62.3 & 13.7 & 7.6 & 45 \\
SS & 20.3 & 9.6 & 87.1 & 19.5 & 9.2 & 77.4 & 96.3 & 95.8 & 88.8 & 66.8 & 31.5 & 265 \\
TF-I & 68.4 & 32.3 & 306 & 66.9 & 31.3 & 306 & 97.9 & 96.8 & 94.5 & 523 & 245 & 2390 \\
TF-II & 172 & 83.3 & 678 & 163 & 82.2 & 641 & 94.6 & 98.6 & 94.5 & 1124 & 567 & 4420 \\
TF-III & 64.0 & 30.2 & 286.3 & 60.9 & 29.1 & 228 & 95.2 & 96.1 & 79.5 & 430 & 205 & 1558 \\
\hline
\end{tabular}

The adsorption capacity $(\mathrm{mg} / \mathrm{kg}$ ) of each filter media at column exhaustion point towards individual heavy metal varied significantly. Values of breakthrough show that the adsorption capacity decreases in the following order: $\mathrm{Zn}>\mathrm{Cu}>\mathrm{Pb}$. This variability is possibly related to the differences in influent concentrations, adsorption affinity (selectivity sequence) as well as weight of filter media. Consequently, adsorption capacity of filter media was found to be in the order of TF-II > TF-I, TF-III > SS > QS. The adsorbent mixture components of TF-I and TF-II (Table 1) were similar, despite for the 3\% dolomite addition in TF-II. Comparison of the adsorption capacities of breakthrough curves evidenced that adsorption of $\mathrm{Cu}, \mathrm{Pb}$ and $\mathrm{Zn}$ onto technical filter media was enhanced in the presence of dolomite. The results of this study eventually supported the theory that presence of dolomite increased the $\mathrm{pH}$ of the solution above solubility point which caused metals to precipitate as metals oxide and probably metals carbonate [13]. The lowest adsorption capacities observed in the filter column packed with natural quartz sand (QS) could be due to its low affinity and non-reactive characteristics which is in agreement with a previous study using sand for metal removal $[4,26]$. 


\subsection{Filter Media Lifespan}

The lifespans will be dependent on needed removal efficiencies and effluent water quality requirements. Size of the stormwater treatment system relative to its impervious catchment area allows designers to predict lifespan of a filter media regarding adsorptive removal of heavy metals. Based on the cumulative heavy metal loading (Table 5) the investigated filter media could be sized at $4 \%$ (SS), $1 \%$ (TF-I and TF-III) and $0.4 \%$ (TF-II) of their impervious catchment size. In order to meet the required removal efficiencies of $80 \%$ for $\mathrm{Cu}$ and $50 \%$ for $\mathrm{Zn}$, predicated lifespans of the filter media were at least 35, 36, 41 and 29 years for SS, TF-I, TF-II and TF-III, respectively. The lifespans determined in the present study are relatively high compared to other studies [18,25]. For example, mixed media composed of perlite, dolomite and gypsum showed an estimated lifespan from 14 to 22 years for $\mathrm{Cu}$ and $\mathrm{Zn}$ [18]. The variability of estimated lifespan might be attributed to the filter media composition, influent concentration, filter bed depth, size of the treatment system relative to its impervious catchment area.

In practice, lifespan of stormwater infiltration/filtration is usually highly dependent on mitigating sediment input to the system. Solids in stormwater might settled out at the surface of filtration system forming a cake layer or are removed in the pores of the filter bed via filtration are considered to play a vital role in reducing the hydraulic performance of the filtration system due to physical clogging. Clogging of filter media is recognised as the main limiting factor regarding the operational lifespan of stormwater infiltration/filtration systems [2,20]. A previous study of stormwater filtration systems constructed with filter media similar to TF-I showed a significant decrease in the infiltration capacity of the systems after five to seven years of operation due to the formation of a clogging layer at the surface of the filters, while the lifespan regarding heavy metal removal was 30 years [20]. The authors suggested that the hydraulic performance of the system could be recovered by scraping off the surface accumulated particle layer and replacement or back flushing of the geotextile on periodic bases, approximately every 7 years. Further research should seek to understand the clogging phenomena of filter media receiving particles and contaminants that mimic the real conditions

\section{Conclusions}

In the present study, the simultaneous adsorption of heavy metals $(\mathrm{Cu}, \mathrm{Pb}$ and $\mathrm{Zn})$ from synthetic stormwater runoff aqueous solutions using quartz sand (QS), sandy soil (SS) and three mineral-based technical filter media (TF-I, TF-II and TF-II) was investigated. The column study result was also used to evaluate effect of de-icing salt $(\mathrm{NaCl})$ on the mobility of retained metals, size of treatment system relative to its imperious catchment area and predict infiltration/filtration system lifespan. The results demonstrate that soil based and mineral-based technical filter media are potentially efficient for the removal of heavy metals under high hydraulic loading conditions. Nearly all effluent concentrations measured during the infiltration of synthetic highway and roof runoff fulfilled the requirements of the Austrian regulations $(9 \mu \mathrm{g} / \mathrm{L} \mathrm{Pb}$ and $1800 \mu \mathrm{g} / \mathrm{L} \mathrm{Cu})$. Additionally, required removal efficiencies for $\mathrm{Cu}(80 \%)$ and $\mathrm{Zn}(50 \%)$ were met during the whole experimental run. However, effluents of $\mathrm{Cu}$ from QS column exceeded the required levels of $1800 \mu \mathrm{g} / \mathrm{L}$, and the required removal efficiencies $\mathrm{Cu}$ and $\mathrm{Zn}$ were not met. Application of the de-icing salt $(\mathrm{NaCl})$ minor effect on the remobilization for most heavy metals adsorbed heavy metals from the sandy soil and all technical filter media columns and all effluent concentrations fulfil the Austrian regulations. However, results from the natural quartz sand (QS) column showed approximately $6.8 \%, 5.2 \%$ and $22 \%$ of the retained $\mathrm{Pb}, \mathrm{Cu}$ and $\mathrm{Zn}$ respectively, were leached in response to $\mathrm{NaCl}$ application as well as effluent concentrations of $\mathrm{Pb}$ and $\mathrm{Cu}$ exceeded the maximum allowable concentration.

Results of long-term treatment performance (Breakthrough curves) demonstrated that mineral-based technical filter media are able to treat higher volumes of stormwater in small filtration systems relative to their impervious catchment area ( 0.4 to $1.0 \%)$ so that they are potentially suitable for utilization in compact stormwater treatment, particularly in urban landscapes where space is very limited. Breakthrough of $\mathrm{Cu}, \mathrm{Pb}$ and $\mathrm{Zn}$ is not expected to occur during the operating life of a 
filter. Physical clogging will occur first limiting the lifespan of infiltration/filtration treatment system. The authors suggested that geotextiles could be installed at the top of the filtration system to act as a barrier to avoid stormwater runoff particles from reaching and clogging the main filter bed. The geotextile filter and accumulated particle layer could be scraped off and replaced at a desired time interval depending on site constraints and clogging rates.

Author Contributions: T.M.H. and M.F. designed, performed, and evaluated the experiments. T.M.H. wrote the original draft of the manuscript, while M.F. reviewed and edited the manuscript. Both authors contributed equally to the Sections 3 and 4 .

Funding: This research was funded by the Austrian Federal Ministry of Agriculture, Forestry, Environment and Water Management (BMLFUW) grant number [GZ B100121]. The company SW-Umwelttechnik is also gratefully acknowledged for providing funds.

Acknowledgments: We sincerely thank the laboratories at the Institute of Hydraulics and Rural Water Management and Institute of Sanitary Engineering and Water Pollution Control (University of Natural Resources and Life Sciences, Vienna) for conducting the analysis.

Conflicts of Interest: The authors declare no conflict of interest.

\section{References}

1. Göbel, P.; Dierkes, C.; Coldewey, W.G. Storm water runoff concentration matrix for urban areas. J. Contam. Hydrol. 2007, 91, 26-42. [CrossRef] [PubMed]

2. Hatt, B.E.; Fletcher, T.D.; Deletic, A. Hydraulic and pollutant removal performance of fine media stormwater filtration systems. Environ. Sci. Technol. 2008, 42, 2535-2541. [CrossRef]

3. Helmreich, B.; Hilliges, R.; Schriewer, A.; Horn, H. Runoff pollutants of a highly trafficked urban road-Correlation analysis and seasonal influences. Chemosphere 2010, 80, 991-997. [CrossRef] [PubMed]

4. Genc-Fuhrman, H.; Mikkelsen, P.S.; Ledin, A. Simultaneous removal of As, Cd, Cr, Cu, Ni and $\mathrm{Zn}$ from stormwater: Experimental comparison of 11 different sorbents. Water Res. 2007, 41, 591-602. [CrossRef] [PubMed]

5. Hatt, B.E.; Steinel, A.; Deletic, A.; Fletcher, T.D. Retention of heavy metals by stormwater filtration systems: Breakthrough analysis. Water Sci. Technol. 2011, 64, 1913-1919. [CrossRef] [PubMed]

6. Huber, M.; Hilbig, H.; Badenberg, S.C.; Fassnacht, S.; Drewes, J.E.; Helmreich, B. Heavy metal removal mechanisms of sorptive filter materials for road runoff treatment and remobilization under de-icing salt applications. Water Res. 2016, 102, 453-463. [CrossRef] [PubMed]

7. Marsalek, J.; Rochfort, Q.; Brownlee, B.; Mayer, T.; Servos, M. An exploratory study of urban runoff toxicity. Water Sci. Technol. 1999, 39, 33-39. [CrossRef]

8. Wium-Andersen, T.; Nielsen, A.H.; Hvitved-Jakobsen, T.; Vollertsen, J. Heavy metals, PAHs and toxicity in stormwater wet detention ponds. Water Sci. Technol. 2011, 64, 503-511. [CrossRef] [PubMed]

9. Haile, T.M.; Mišík, M.; Grummt, T.; Halh, A.-S.; Pichler, C.; Knasmueller, S.; Fuerhacker, M. Cytotoxic and genotoxic activities of waters and sediments from highway and parking lot runoffs. Water Sci. Technol. 2016, 73, 2772-2780. [CrossRef] [PubMed]

10. Shinya, M.; Tsuchinaga, T.; Kitano, M.; Yamada, Y.; Ishikawa, M. Characterization of heavy metals and polycyclic aromatic hydrocarbons in urban highway runoff. Water Sci. Technol. 2000, 42, 201-208. [CrossRef]

11. Eriksson, E.; Baun, A.; Scholes, L.; Ledin, A.; Ahlman, S.; Revitt, M.; Noutsopoulos, C.; Mikkelsen, P.S. Selected stormwater priority pollutants d a European perspective. Sci. Total Environ. 2007, 383, 41-51. [CrossRef] [PubMed]

12. Scholes, L.; Revitt, M.D.; Ellis, J.B. A systematic approach for the comparative assessment of stormwater pollutant removal potentials. J. Environ. Manag. 2008, 88, 467-478. [CrossRef] [PubMed]

13. Reddy, K.R.; Xie, T.; Dastgheibi, S. Mixed-Media Filter System for Removal of Multiple Contaminants from Urban Storm Water: Large-Scale Laboratory Testing. J. Hazard. Toxic Radioact. Waste 2014, 18, 04014011. [CrossRef]

14. Hilliges, R.; Schriewer, A.; Helmreich, B. A three-stage treatment system for highly polluted urban road runoff. J. Environ. Manag. 2013, 128, 306-312. [CrossRef] [PubMed]

15. Pawluk, K.; Fronczyk, J. Evaluation of single and multilayered reactive zones for heavy metals removal from stormwater. Environ. Technol. 2015, 36, 1576-1583. [CrossRef] [PubMed] 
16. Fuerhacker, M.; Haile, T.M.; Monai, B.; Mentler, A. Performance of a filtration system equipped with filter media for parking lot runoff treatment. Desalination 2011, 275, 118-125. [CrossRef]

17. Pitcher, S.K.; Slade, R.C.T.; Wards, N.I. Heavy metal removal from motorway stormwater using zeolites. Sci. Total Environ. 2004, 334-335, 161-166. [CrossRef] [PubMed]

18. Thomas, A.; Haselbach, L.; Poor, C.; Freimund, M. Long-term metal retention performance of media filter drains for stormwater management. Sustainability 2015, 7, 3721-3733. [CrossRef]

19. Hsieh, C.H.; Davis, A.P. Multiple-event study of bioretention for treatment of urban storm water runoff. Water Sci. Technol. 2005, 51, 177-181. [CrossRef] [PubMed]

20. Haile, T.M.; Hobiger, G.; Kammerer, G.; Allabashi, R.; Schaerfinger, B.; Fuerhacker, M. Hydraulic Performance and Pollutant Concentration Profile in a Stormwater Runoff Filtration Systems. Water Air Soil Pollut. 2016, 227, 34. [CrossRef]

21. Lim, H.S.; Lim, W.; Hu, J.Y.; Ziegler, A.; Ong, S.L. Comparison of filter media materials for heavy metal removal from urban stormwater runoff using biofiltration systems. J. Environ. Manag. 2015, 147, $24-33$. [CrossRef] [PubMed]

22. Athanasiadis, K. On-Site Infiltration of Roof Runoff by Using Clinoptilolite as an Artificial Barrier Material. Ph.D. Thesis, Technical University of Munich, München, Germany, 2005.

23. Nguyen, T.C.; Loganathan, P.; Nguyen, T.V.; Vigneswaran, S.; Kandasamy, J.; Naidu, R. Simultaneous adsorption of $\mathrm{Cd}, \mathrm{Cr}, \mathrm{Cu}, \mathrm{Pb}$, and $\mathrm{Zn}$ by an iron-coated Australian zeolite in batch and fixed-bed column studies. Chem. Eng. J. 2015, 270, 393-404. [CrossRef]

24. Wang, J.; Zhao, Y.; Yang, L.; Tu, N.; Xi, G.; Fang, X. Removal of Heavy Metals from Urban Stormwater Runoff Using Bioretention Media Mix. Water 2017, 9, 854. [CrossRef]

25. Monrabal-Martinez, C.; Ilyas, A.; Muthanna, T.M. Pilot Scale Testing of Adsorbent Amended Filters under High Hydraulic Loads for Highway Runoff in Cold Climates. Water 2017, 9, 230. [CrossRef]

26. Seelsaen, N.; McLaughlan, R.; Moore, S.; Ball, J.E.; Stuetz, R.M. Pollutant removal efficiency of alternative filtration media in stormwater treatment. Water Sci. Technol. 2006, 54, 299-305. [CrossRef] [PubMed]

27. Bäckström, M.; Karlsson, S.; Bäckman, L.; Folkeson, L.; Lind, B. Mobilisation of heavy metals by deicing salts in a roadside environment. Water Res. 2004, 38, 720-732. [CrossRef] [PubMed]

28. Norrström, A.C. Metal mobility by de-icing salt from an infiltration trench for highway runoff. Appl. Geochem. 2005, 20, 1907-1919. [CrossRef]

29. Bauske, B.; Goetz, D. Effects of deicing salts on heavy metal mobility. Acta Hydrochim. Hydrobiol. 1993, 21, 38-42. [CrossRef]

30. Österreichische Institut für Normung. Regenwasser-Sickeranlagen für Abläufe von Dachflächen und befestigten Flächen-Teil 3: Filtermaterialen-Anforderungen und Prüfmethoden. [Soakaways for Rain Water from Roof Gutters and Reinforced Surfaces_-Part 3: Filter Materials_Requirements and Tests]; ÖNORM B 2506-3; Österreichische Institut für Normung: Vienna, Austria, 2016; pp. 1-27. (In German)

31. DIBt. Zulassungsgrundsätze für Niederschlagswasserbehandlungsanlagen. Teil 1: Anlagen zum Anschluss von Kfz-Verkehrsflächen bis $2.000 \mathrm{~m}^{2}$ und Behandlung des Abwassers zur anschließenden Versickerung in Boden und Grundwasser; Deutsches Institut für Bautechnik: Berlin, Germany, 2011; pp. 1-20. (In German)

32. Nelson, S.; Yonge, D.; Barber, M. Effects of Road Salts on Heavy Metal Mobility in Two Eastern Washington Soils. J. Environ. Eng. 2009, 135, 505-510. [CrossRef]

33. Acosta, J.A.; Jansen, B.; Kalbitz, K.; Faz, A.; Martínez-Martínez, S. Salinity increases mobility of heavy metals in soils. Chemosphere 2011, 85, 1318-1324. [CrossRef] [PubMed]

34. Alloway, B.J. Bioavailability of elements in soil. In Essentials of Medical Geology; Selinus, O., Alloway, B.J., Centeno, A.R., Finkelman, B., Fuge, R., Lindh, U., Smedley, P., Eds.; Springer: Dordrecht, The Netherlands, 2005; pp. 347-372.

35. Arshadi, M.; Amiri, M.J.; Mousavi, S. Kinetic, equilibrium and thermodynamic investigationsof Ni(II), Cd(II), $\mathrm{Cu}(\mathrm{II})$ and $\mathrm{Co}(\mathrm{II})$ adsorption on barley straw ash. Water Resour. Ind. 2014, 6, 1-17. [CrossRef]

36. Fürhacker, M.; Haile, T.M.; Schärfinger, B.; Kammerer, G.; Allabashi, R.; Magnat, S.; Lins, A. Entwicklung von Methoden zur Prüfung der Eignung von Substraten für die Oberflächenwasserbehandlung von Dach- und Verkehrsflächen; Fördervertrag GZ B100121; University of Natural Resources and Life Sciences: Vienna, Austria, 2013; pp. 1-240. (In German)

37. Huber, M.; Welker, A.; Helmreich, B. Critical review of heavy metal pollution of traffic area runoff: Occurrence, influencing factors, and partitioning. Sci. Total Environ. 2016, 541, 895-919. [CrossRef] [PubMed] 
38. Fanfan, P.N.; Mabon, N.; Carletti, I.; Claustriaux, J.J.; Thonart, P.; Lognay, G.; Copin, A.; Barthélemy, J.P. New model for performance prediction in fixed-bed reactors based on the approach of the unused bed zone. Water Res. 2005, 39, 4004-4010. [CrossRef] [PubMed]

39. BMFLUW. Verordnung des Bundesministers für Land-und Forstwirtschaft, Umwelt und Wasserwirtschaft über den guten chemischen Zustand des Grundwassers (Qualitatszielverordnung Chemie Grundwasser-QZV Chemie GW); BGBl. II Nr. 98/2010; BMFLUW: Austria, Vienna, 2010; pp. 1-10. (In German)

40. Genc-Fuhrman, H.G.; Wu, P.; Zhou, Y.; Ledin, A. Removal of As, Cd, Cr, Cu, Ni and Zn from polluted water using an iron based sorbent. Desalination 2008, 226, 357-370. [CrossRef]

41. Bradl, H.B. Adsorption of heavy metal ions on soils and soils constituents. J. Colloid Interface Sci. 2004, 277, 1-18. [CrossRef] [PubMed]

42. Atanassova, I.D. Adsorption and desorption of $\mathrm{Cu}$ at high equilibrium concentrations by soil and clay samples fromBulgaria. Environ. Pollut. 1995, 87, 17-21. [CrossRef]

43. Inglezakis, V.J.; Hadjiandreou, K.J.; Loizidou, M.D.; Grigoropoulou, H.P. Pretreatment of natural clinoptilolite in a laboratory-scale ion exchange packed bed. Water Res. 2001, 35, 2161-2166. [CrossRef]

(C) 2018 by the authors. Licensee MDPI, Basel, Switzerland. This article is an open access article distributed under the terms and conditions of the Creative Commons Attribution (CC BY) license (http://creativecommons.org/licenses/by/4.0/). 